\title{
Ad multos annos! Meeting with an anatomist in 1986 as an orthopedist
}

\author{
Jürgen Rütt \\ Professor of Orthopaedic Surgery, Cologne, Germany \\ Anatomy 2012-2013;6-7:6, ( 2012-2013 TSACA
}

I contacted Jürgen Koebke, who was the Chief of the Study Group of Functional Anatomy and Biomechanics in the anatomical institute of the university that I worked, during the preparation period of my professorship thesis entitled as "patellar Subluxation in Rabbits". He helped me to complete my work successfully by directing, correcting and supporting me, "the surgeon", in a great devotion. Through this association, both a scientific cooperation and a personal friendship were born. Together with postgraduates, we scientifically worked on researches finding answers on macroscopic sense to the questions about the reasons of various orthopedic problems. In the meantime, his humble personality and highly appreciated scientific capacity was regarded by the postgraduates as well. Surgical courses must also be emphasized, during which countless young doctors from various disciplines learned their first private initiatives through the use of extraordinary anatomical preparations. During a common congress visit (GermanTurkish Orthopedic Surgeons' Meeting), Koebke met with Istanbul and loved the city. A very personal and scientific communication was established between him and Istanbulian anatomists that he contacted after a while. As of the end of 90s, this collaboration has been intensified by the mutual visits between Istanbul and Cologne every year. One of the greatest desires of Koebke besides scientific exchanges was to show his hospitality in Cologne as well. Jürgen Koebke established connections not only with Turkey but also with other countries. Over the years, I witnessed how Jürgen has established international connections with Rostow in Russia, Varna in Bulgaria, and Thessaloniki in Greece. His greatest desire and goal was to support the education of students and to establish a connection between macro-anatomy and surgical courses, particularly the hand surgery and orthopedics.

Thanks to his modest style, outstanding scientific competence, and the persuasive rhetoric, he was appreciated everywhere with his presentations. He valued much not only scientific way but also personal friendships. Jürgen Koebke was not one of those who were uttering humanism theoretically; he lived it together with his friends. His office was always open for everyone. Macroanatomy field lost a perfect representative who never lost his intense love for the students.

\footnotetext{
Correspondence to: Professor Jürgen Rütt, MD Am Apostelhof 9, 50226 Frechen, Germany e-mail: j.ruett47@gmail.com

Conflict of interest statement: No conflicts declared.
} 